\title{
Empirical Analysis of Job Satisfaction in Relation to Motivation
}

\author{
Satinder $\operatorname{Kumar}^{1}$, Jitender Kaur ${ }^{2}$ \\ ${ }^{I}$ (Assistant Professor, School of Management Studies/Punjabi University Patiala, India) \\ ${ }^{2}$ (Research Scholar, Department of Tourism, Hospitality \& Hotel Management/ Punjabi University Patiala, \\ India)
}

\begin{abstract}
This research is done to study the relation between motivation and job satisfaction and to study the impact of motivation on the satisfaction level of teachers. In this research the student also study the satisfaction level of teachers. The need of this research is to study the satisfaction level of teachers as well as influence of motivational factors on the job satisfaction factors. In these days both motivation study the motivation and satisfaction level of employees to increase the productivity of work. This research is done to find out which factors motivate/boost the satisfaction level of teachers to increase their job satisfaction. Most of respondents are satisfied with good infrastructure, working hours and interpersonal relationships with colleagues, administers and students. If they have good relationships with colleagues then their level of satisfaction will high. Teachers are satisfied with the statement that student's feedback acts as a motivation for them. The data was collected from 50 University Teachers. The Teachers were surveyed by questionnaire. The sample was drawn by using the convenient Non-random sampling technique.
\end{abstract}

Keywords-interpersonal relationships, job-satisfaction, motivation, productivity and recognition.

\section{INTRODUCTION}

Teachers are the pillars of the society, who help students to grow to shoulder the responsibility of taking their nation ahead of others. They desire security, recognition, new experience and independence. When these needs are not fulfilled they become tense. Dissatisfaction among workers is undesirable and dangerous in any profession; it is suicidal if it occurs in teaching profession. If factors responsible for dissatisfaction can be differentiated, attempts can be made either to change those conditions or to reduce their intensity so as to increase the holding power of the profession. This study attempts to find out relation between motivate on and job satisfaction of university teachers. Motivation is an important factor which encourages persons to give their best performance and help in reaching enterprise goals. A strong positive motivation will enable the increased output of employee but a negative motivation will reduce their performance. Motivation is the core of management which shows that every human being gives him a sense of worth in face to face groups which are most important to him. Motivation is the complex of forces starting and keeping a person at work in an organization. Motivation is the driving force which help causes us to achieve goals. The present study takes into account intrinsic and extrinsic factors to find out the level of job satisfaction and to see the effect of age, gender, marital status, education, occupation level and length of employment on the job satisfaction of academicians.

a. Intrinsic Factors-Intrinsic satisfaction to the teachers can come from classroom activities. Daily interactions with students inform teachers' feelings about whether or not students have learned something as a result of their teaching..Intrinsic factors play a significant role in motivating individuals to enter the teaching profession because they enjoy teaching and want to work with young people. Very few teachers enter the profession because of external rewards such as salary, benefits, or prestige.

b. Extrinsic Factors-A variety of extrinsic factors have been associated with teacher satisfaction including salary, perceived support from administrators, school safety, and availability of school resources, among others.

c. Demographic Factors- job satisfaction in teachers has been related to demographic variables including age, education, marital status and gender.

\section{Theories of Job - Satisfaction:}

a. Herzberg's Motivation- Hygiene Theory

b. Need fulfilment theory.

c. Social reference - group theory. 
Herzberg's Motivation - Hygiene Theory: This theory was proposed by Herzberg \& his assistants in 1969. On the basis of his study of 200 engineers and accountants of the Pittsburgh area in the USA, he established that there are two separate sets of conditions (and not one) which are responsible for the motivation \& dissatisfaction of workers. When one set of conditions (called 'motivator') is present in the organization, workers feel motivated but its absence does not dissatisfy them. Similarly, when another set of conditions (called hygiene factors) is absent in the organization, the workers feel dissatisfied but its presence does not motivate them. The two sets are unidirectional, that is, their effect can be seen in one direction only.

Need Fulfilment Theory: Under the need-fulfilment theory it is believed that a person is satisfied if he gets what he wants \& the more he wants something or the more important it is to him, the more satisfied he is when he gets it $\&$ the more dissatisfied he is when he does not get it. Needs may be need for personal achievement, social achievement $\&$ for influence.

a. Need for personal achievement

b. Need for social achievement.

c. Need for influence

Social References - Group Theory: It takes into account the point of view \& opinions of the group to whom the individual looks for the guidance. Such groups are defined as the 'reference-group' for the individual in that they define the way in which he should look at the world and evaluate various phenomena in the environment (including him). It would be predicted, according to this theory that if a job meets the interest, desires and requirements of a person's reference group, he will like it \& if it does not, he will not like it.A good example of this theory has been given by C.L. Hulin. He measures the effects of community characteristics on job satisfaction of female clerical workers employed in 300 different catalogue order offices. He found that with job conditions held constant job satisfaction was less among persons living in a well-to-do neighbourhood than among those whose neighbourhood was poor.

\section{REVIEW OF LITERATURE}

Maslow's (1943) opined need-based theory of motivation is the most commonly known theory of motivation according to which there are five fundamental needs of a person i.e., physiological, security, affiliation, esteem, and self-actualization. This theory can be true for teachers by understanding their physiological needs that may include pay, benefits, health and medical facility, accommodation and transportation, and comfortable working environment. A teacher' security needs are similar to any other employee who is always concerned about his/her job security, fair treatment, protection against threats and many more. Affiliation needs of a teacher can be the liking of head towards him, participation in departmental decisions, acceptance from colleagues and co-workers etc. whereas esteem needs of teachers may include the need for recognition from the departmental head, colleagues, subordinate, and students.

Bohlender et al (2001) stressed upon compensation as one of the important considerations in human resource management. They emphasized that it is a tangible reward to the employees for the services; therefore compensation must be in accordance to the need fulfilment of employees. Nirmala (2002), in his research found professional growth as fundamental motivators for teachers. He further described that teacher's professional learning is a component of their career development that gives them effectiveness and satisfaction in teaching.

Lynn (2002) supported the idea that educational leaders should provide professional learning and growth opportunities in order to motivate teachers and to enhance their performance. Mahajan (2002), concluded in his research that high workload, large number of students in classes and burden of non teaching activities are the problems in creating a good job design for teachers in higher education institutions.

Filak \& Sheldon, (2003) put their opinion that the motivation is crucial to the long term success and performance of any educational system. Ololube (2004) explored the same point of view that increased motivation of teachers' leads to an increase in productivity that gives boost to the educational systems; hence the function of educations motivational methods cannot be underemphasized. Different theories of motivation like Maslow's hierarchy of need theory, Herzberg's motivation hygiene theory and Adam's Equity theory are been stated in literature. These theories provide fundamental basis of motivation that help describing the motivation 
of employees in a systematic way and in understanding the contemporary theories of motivation like goal setting theory, reinforcement theory and expectancy theory etc.

Robbins et al (2005). Any organization cannot sustain without increased workers' motivation that is inevitable in the current scenario of hyper competition in corporate world. Robbins et al said that employee's motivation is the "willingness to exert high level of inspiration to reach Organizational goals, conditioned by the efforts ability to satisfy some individual need". This definition clearly states that motivation is the willingness of employees to perform excellent work efficiently and this willingness only comes when they perceive that their effort would result in their need satisfaction. Employee's motivation can only be attained by realizing him/her that his individual needs or goals are aligned with organizational goals or achievement. Organizations need to extract various internal and external motivators for its workers so that they can increase their motivation in order to get long run success.

Aziri (2011). states that there is no agreed upon definition of what job satisfaction is or what it represents; but there is need to consider the nature and importance of the work. Bentea and Anghelache (2012). conducted a study aimed to test if were differences in the levels of job satisfaction varying with the gender, the professional position given by the level of continuous training held (through tenure and teaching degrees) and the dominant needs. The results did not indicate any differences between men and women in overall job satisfaction and its dimensions but satisfaction is affected by the level of continuous training. Also, job satisfaction was found to be influenced by the intensity of the needs of achievement and affiliation.

Hoffman-Miller, (2013) Job satisfaction focuses on three components of organizational behaviour: that is cognitive, affective, and behavioural and is widely used to determine overall satisfaction in human capital management. According to Thahier et al. (2014), motivating employees is very important because motivation of every individual is his willingness to unreservedly work hard for high productivity meaning the employee is willing to use all the abilities that he has for the sake of his organization by utilizing the available opportunities to accomplish his organization's mission.

\section{RESEARCH METHODOLOGY}

Research Design: Descriptive research is undertaken to achieve the stated objectives of the present study. Personal investigation involving filling questionnaires and collecting data of the respective fields through meetings with the respondents had helped to explore greater insight into all possible practical aspects of the research problem.

\section{Collection of data:}

1. Primary Data: - A questionnaire prepared and individually administrated to gather data from the selected population.

2. Secondary Data:- Source of secondary data include journals, magazines, websites all this helped in authenticating the kind of information we obtained our sources and thus helped to get a very objective view of the study.

Sampling Technique: Convenience sampling method has been used because selection of units from the population has been based on easy availability and/or accessibility. The teachers have been selected from following departments: SMS Department, Chemistry Department, Physics Department and Law Department. the sample size is of 50 teachers. The teachers have been selected from different departments to fill the questionnaire.

IV. ANALYSIS AND INTERPRETATION

TABLE I: Opportunity to Start Over in a New Career, Would you choose to become a university teacher

\begin{tabular}{|l|l|l|l|l|l|}
\hline Parameter & $\begin{array}{l}\text { Extremely } \\
\text { agree }\end{array}$ & $\begin{array}{l}\text { Somewhat } \\
\text { agree }\end{array}$ & Neutral & $\begin{array}{l}\text { Somewhat } \\
\text { disagree }\end{array}$ & $\begin{array}{l}\text { Not agree at } \\
\text { all }\end{array}$ \\
\hline $\begin{array}{l}\text { If you had opportunity to start over in } \\
\text { a new career, would you choose to } \\
\text { become a university teacher? }\end{array}$ & 36 & 14 & & & \\
\hline
\end{tabular}


The above analysis shows that mostly respondent are agree with the statement. They would like to become university teacher if they had opportunity to start over in a new career. Because in teaching job at university they have job security, good salary, potential for professional growth, adequate working hours etc. they are satisfied with the job as teachers in university.

TABLE II: Generally Speaking, do You Believe that University Teachers with whom You Work are Motivated

\begin{tabular}{|l|l|l|l|l|l|}
\hline Parameter & $\begin{array}{l}\text { Extremely } \\
\text { Agree }\end{array}$ & $\begin{array}{l}\text { Somewhat } \\
\text { Agree }\end{array}$ & Neutral & $\begin{array}{l}\text { Somewhat } \\
\text { Disagree }\end{array}$ & Not agree at all \\
\hline $\begin{array}{l}\text { Generally } \\
\text { speaking, do } \\
\text { you believe that } \\
\text { university } \\
\text { teachers with } \\
\text { whom you work } \\
\text { are motivated? }\end{array}$ & 24 & 21 & 3 & 2 & \\
\hline
\end{tabular}

The above table shows that most of the respondents are satisfied with given statement. They feel that university teachers are motivated with whom they work. The teachers are motivated because of new UGC guidelines that all the teachers have to complete CAS score. Without fulfilling this Norms they cannot be promoted.

Job Satisfaction Factors:

TABLE III. Level of Satisfaction

\begin{tabular}{|l|l|l|l|l|l|}
\hline Parameter & $\begin{array}{l}\text { Extremely } \\
\text { Satisfied }\end{array}$ & $\begin{array}{l}\text { Somewhat } \\
\text { Satisfied }\end{array}$ & Neutral & $\begin{array}{l}\text { Somewhat } \\
\text { Dissatisfied }\end{array}$ & $\begin{array}{l}\text { Not satisfied at } \\
\text { all }\end{array}$ \\
\hline $\begin{array}{l}\text { Your overall } \\
\text { level }\end{array}$ & 26 & 18 & 6 & & \\
$\begin{array}{l}\text { satisfaction with } \\
\text { your job as a } \\
\text { teacher. }\end{array}$ & & & & & \\
\hline
\end{tabular}

The above depicts that most of the respondents are satisfied with their overall level of satisfaction with their job as a teacher. Because they are getting good salary, adequate infrastructure, working hours, job security, professional growth, good network and recognition.

TABLE IV. Adequate Infrastructures

\begin{tabular}{|l|l|l|l|l|l|}
\hline Parameter & Extremely & Somewhat & Neutral & Somewhat & $\begin{array}{l}\text { Not satisfied at } \\
\text { all }\end{array}$ \\
\hline $\begin{array}{l}\text { Are you } \\
\text { provided with } \\
\text { adequate } \\
\text { infrastructure? }\end{array}$ & 17 & 22 & 8 & 3 & \\
\hline
\end{tabular}

The above analysis depicts that most of respondents are satisfied with the given statement. Infrastructure plays very important role in the job satisfaction of teachers. Good infrastructure increases the satisfaction level of teachers. If they are provided with good infrastructure then their level of satisfaction is high. Some of respondents are not satisfied with the given statement because they are not provided with adequate infrastructure. 
TABLE V. Working Hours

\begin{tabular}{|l|l|l|l|l|l|}
\hline Parameter & $\begin{array}{l}\text { Extremely } \\
\text { Satisfied }\end{array}$ & $\begin{array}{l}\text { Somewhat } \\
\text { Satisfied }\end{array}$ & Neutral & $\begin{array}{l}\text { Somewhat } \\
\text { dissatisfied }\end{array}$ & $\begin{array}{l}\text { Not satisfied at } \\
\text { all }\end{array}$ \\
\hline $\begin{array}{l}\text { Are you satisfied } \\
\text { with } \\
\text { hours? }\end{array}$ & 23 & 16 & 10 & 1 & \\
\hline
\end{tabular}

The above analysis shows that most of respondents are satisfied with given statement. Only one respondent is somewhat dissatisfied with the working hours. Most of teachers are satisfied with given statement that adequate working hours have great affect on their satisfaction level of job. If they work for long hours then they feel stress which causes less job satisfaction in teachers. The job becomes hectic for them and they will be less satisfied from their job.

TABLE VI. Recognition

\begin{tabular}{|l|l|l|l|l|l|}
\hline Parameter & $\begin{array}{l}\text { Extremely } \\
\text { Satisfied }\end{array}$ & $\begin{array}{l}\text { Somewhat } \\
\text { Satisfied }\end{array}$ & Neutral & $\begin{array}{l}\text { Somewhat } \\
\text { dissatisfied }\end{array}$ & $\begin{array}{l}\text { Not satisfied at } \\
\text { all }\end{array}$ \\
\hline Recognition & 19 & 15 & 14 & 2 & \\
\hline
\end{tabular}

Mostly respondents are satisfied with the given statement. But two respondents are dissatisfied with the statement. They feel that recognition do not affect their level of satisfaction. But most of respondent are affected by the recognition. Due to recognition their level of satisfaction increases. Praise from administer, parents, students etc has great affect on job satisfaction level of teachers.

TABLE VII. Potential for Professional Growth

\begin{tabular}{|l|l|l|l|l|l|}
\hline Parameter & $\begin{array}{l}\text { Extremely } \\
\text { Satisfied }\end{array}$ & $\begin{array}{l}\text { Somewhat } \\
\text { Satisfied }\end{array}$ & Neutral & $\begin{array}{l}\text { Somewhat } \\
\text { dissatisfied }\end{array}$ & Not satisfied at all \\
\hline Potential for professional growth & 14 & 16 & 17 & 3 & \\
\hline
\end{tabular}

The above table shows that $28 \%$ respondents are extremely satisfied, $32 \%$ are somewhat satisfied, $34 \%$ are neutral, and $6 \%$ are somewhat dissatisfied. The dissatisfied respondents feel that their professional growth does not affect their satisfaction level. But satisfied respondents feel that their professional growth affects their level of satisfaction. If they get good potential for professional growth then they are more satisfied towards their job.

TABLE VIII. Interpersonal Relationships with Colleagues:

\begin{tabular}{|l|l|l|l|l|l|}
\hline Parameter & $\begin{array}{l}\text { Extremely } \\
\text { Satisfied }\end{array}$ & $\begin{array}{l}\text { Somewhat } \\
\text { Satisfied }\end{array}$ & Neutral & $\begin{array}{l}\text { Somewhat } \\
\text { dissatisfied }\end{array}$ & $\begin{array}{l}\text { Not satisfied at } \\
\text { all }\end{array}$ \\
\hline $\begin{array}{l}\text { Interpersonal } \\
\text { relationships } \\
\text { with colleagues }\end{array}$ & 22 & 19 & 8 & 1 & \\
\hline
\end{tabular}

Mostly respondents are satisfied with the given statement. It means interpersonal relation with the colleagues has great affect on the job satisfaction of teachers. Their good interpersonal relationships with colleagues increase their satisfaction level towards their job. Good interpersonal relationships with colleagues increase the satisfaction of teachers towards their job.

TABLE IX. Salary

\begin{tabular}{|l|l|l|l|l|l|}
\hline Parameter & $\begin{array}{l}\text { Extremely } \\
\text { Satisfied }\end{array}$ & $\begin{array}{l}\text { Somewhat } \\
\text { Satisfied }\end{array}$ & Neutral & $\begin{array}{l}\text { Somewhat } \\
\text { dissatisfied }\end{array}$ & $\begin{array}{l}\text { Not satisfied at } \\
\text { all }\end{array}$ \\
\hline
\end{tabular}




\begin{tabular}{|l|l|l|l|l|l|}
\hline Salary & 26 & 14 & 6 & 2 & 2 \\
\hline
\end{tabular}

The above table shows that $52 \%$ respondents are extremely satisfied, $28 \%$ are somewhat satisfied, $12 \%$ are neutral, $4 \%$ are somewhat dissatisfied and $4 \%$ are mat satisfied at all from given statement. Salary has great impact on the satisfaction level of teachers. The teacher with more salary is more satisfied than the teacher with less salary. It means salary plays a major role in the job satisfaction of teachers. Teachers with more salary have high level of satisfaction towards their job.

TABLE X. Job Security

\begin{tabular}{|l|l|l|l|l|l|}
\hline Parameter & $\begin{array}{l}\text { Extremely } \\
\text { Satisfied }\end{array}$ & $\begin{array}{l}\text { Somewhat } \\
\text { Satisfied }\end{array}$ & Neutral & $\begin{array}{l}\text { Somewhat } \\
\text { dissatisfied }\end{array}$ & $\begin{array}{l}\text { Not satisfied at } \\
\text { all }\end{array}$ \\
\hline Job security & 14 & 12 & 18 & 5 & 1 \\
\hline
\end{tabular}

Mostly respondents are neutral from above statement. In public sector the job is more secure than in private sector. But teachers on contract base are insecure towards their job. So job security has less impact on the job satisfaction of teachers in public sectors. Teachers in public sector have more job security than teachers in private sector.

TABLE XI. Interpersonal Relationships with Administrators:

\begin{tabular}{|l|l|l|l|l|l|}
\hline Parameter & $\begin{array}{l}\text { Extremely } \\
\text { Satisfied }\end{array}$ & $\begin{array}{l}\text { Somewhat } \\
\text { Satisfied }\end{array}$ & Neutral & $\begin{array}{l}\text { Somewhat } \\
\text { dissatisfied }\end{array}$ & $\begin{array}{l}\text { Not satisfied at } \\
\text { all }\end{array}$ \\
\hline $\begin{array}{l}\text { Interpersonal } \\
\text { relationships } \\
\text { with } \\
\text { administrators }\end{array}$ & 17 & 18 & 11 & 3 & 1 \\
\hline
\end{tabular}

The above table depicts that mostly respondent are satisfied with the given statement. Interpersonal relationships with administers has great impact on the job satisfaction of employees. If teachers has good interpersonal relationships with administers then they do their job very well and have more satisfaction towards their job than the teachers who have bad interpersonal relationships with administers. But some respondent are not satisfied with the given statement they feel that their interpersonal relationships with administers, either good or bad do not affect the satisfaction level towards their job.

TABLE XII. Factors in Personal Life

\begin{tabular}{|l|l|l|l|l|l|}
\hline Parameter & $\begin{array}{l}\text { Extremely } \\
\text { Satisfied }\end{array}$ & $\begin{array}{l}\text { Somewhat } \\
\text { Satisfied }\end{array}$ & Neutral & $\begin{array}{l}\text { Somewhat } \\
\text { dissatisfied }\end{array}$ & $\begin{array}{l}\text { Not satisfied at } \\
\text { all }\end{array}$ \\
\hline $\begin{array}{l}\text { Factorsin } \\
\text { personal life }\end{array}$ & 12 & 30 & 4 & 3 & 1 \\
\hline
\end{tabular}

Mostly employees are somewhat satisfied with above statement. Personal life of a person also affects his job satisfaction. Personal life of female teachers has great affect on the job satisfaction than the male teachers because female teachers have more responsibilities in their personal life than male teachers. Job satisfaction among female teachers is less than male teachers. Personal life plays an important role in the job satisfaction of teachers. If they have some problems in personal life then they will not pay full attention towards their work which decreases their satisfaction level.

TABLE XIII. Interpersonal Relationships with Students

\begin{tabular}{|l|l|l|l|l|l|}
\hline Parameter & $\begin{array}{l}\text { Extremely } \\
\text { Satisfied }\end{array}$ & $\begin{array}{l}\text { Somewhat } \\
\text { Satisfied }\end{array}$ & Neutral & $\begin{array}{l}\text { Somewhat } \\
\text { dissatisfied }\end{array}$ & $\begin{array}{l}\text { Not satisfied at } \\
\text { all }\end{array}$ \\
\hline $\begin{array}{l}\text { Interpersonal } \\
\text { relationships } \\
\text { with students. }\end{array}$ & 23 & 20 & 6 & 1 & \\
\hline
\end{tabular}


The above table shows that most of respondents are satisfied with the given statement. Their good Interpersonal relationships with students increase their level of satisfaction. If teachers have no good Interpersonal relationships with students then their productivity will be low. Their results of teaching will not be good which decreases their level of satisfaction.

TABLE XIV. Student's Positive Feedback Increases the Satisfaction of Teachers

\begin{tabular}{|l|l|l|l|l|l|}
\hline Parameter & $\begin{array}{l}\text { Extremely } \\
\text { Satisfied }\end{array}$ & $\begin{array}{l}\text { Somewhat } \\
\text { Satisfied }\end{array}$ & Neutral & $\begin{array}{l}\text { Somewhat } \\
\text { dissatisfied }\end{array}$ & $\begin{array}{l}\text { Not satisfied at } \\
\text { all }\end{array}$ \\
\hline $\begin{array}{l}\text { Student's } \\
\text { positive } \\
\text { feedback the } \\
\text { increases } \\
\text { satisfaction of } \\
\text { teachers }\end{array}$ & 17 & 22 & 11 & & \\
\hline
\end{tabular}

Mostly respondents are satisfied with above statement. Student's feedback plays great role in job satisfaction of teachers. Feedback from students has great impact on the satisfaction level of teachers. Positive feedback from student increases the satisfaction level of teachers if students are satisfied from their teachers then they will give positive feedback to their teachers which increase the satisfaction level of teachers.

Motivation Factors:

TABLE XV. Infrastructure Motivates the Satisfaction Level of Teachers

\begin{tabular}{|l|l|l|l|l|l|}
\hline Parameter & $\begin{array}{l}\text { Extremely } \\
\text { Satisfied }\end{array}$ & $\begin{array}{l}\text { Somewhat } \\
\text { Satisfied }\end{array}$ & Neutral & $\begin{array}{l}\text { Somewhat } \\
\text { dissatisfied }\end{array}$ & $\begin{array}{l}\text { Not satisfied at } \\
\text { all }\end{array}$ \\
\hline $\begin{array}{l}\text { Infrastructure } \\
\text { motivates the } \\
\text { satisfaction level } \\
\text { of teachers. }\end{array}$ & 25 & 20 & 5 & & \\
\hline
\end{tabular}

The above statement depicts that most of respondents are satisfied with the given statement. Infrastructure plays very important role in the job satisfaction of teachers. Good infrastructure motivates the satisfaction level of teachers. If they are provided with good infrastructure then their level of satisfaction is high. If they are not provided with adequate infrastructure then it will not motivate them which decrease their level of satisfaction.

TABLE XVI. Work Hours Motivate the Teacher's Satisfaction Level:

\begin{tabular}{|l|l|l|l|l|l|}
\hline Parameter & $\begin{array}{l}\text { Extremely } \\
\text { Satisfied }\end{array}$ & $\begin{array}{l}\text { Somewhat } \\
\text { Satisfied }\end{array}$ & Neutral & $\begin{array}{l}\text { Somewhat } \\
\text { dissatisfied }\end{array}$ & $\begin{array}{l}\text { Not satisfied at } \\
\text { all }\end{array}$ \\
\hline $\begin{array}{l}\text { Work hours } \\
\text { motivate the } \\
\text { teacher's } \\
\text { satisfaction } \\
\text { level. }\end{array}$ & 24 & 22 & 4 & & \\
\hline
\end{tabular}

The above table shows that most of respondents are satisfied with given statement. Most of teachers are satisfied with given statement that adequate working hours have great affect on their satisfaction level of job. If they work for long hours then they feel stress which causes less job satisfaction in teachers. The job becomes hectic for them, they will become frustrate from their job and they will be less satisfied from their job. So adequate working hours motivates satisfaction level of teachers.

TABLE XVII. Recognition Motivates the Teachers

\begin{tabular}{|l|l|l|l|l|l|}
\hline Parameter & $\begin{array}{l}\text { Extremely } \\
\text { Satisfied }\end{array}$ & $\begin{array}{l}\text { Somewhat } \\
\text { Satisfied }\end{array}$ & Neutral & $\begin{array}{l}\text { Somewhat } \\
\text { dissatisfied }\end{array}$ & $\begin{array}{l}\text { Not satisfied at } \\
\text { all }\end{array}$ \\
\hline
\end{tabular}


IOSR Journal of Business and Management (IOSR-JBM) e-ISSN: 2278-487X, p-ISSN: 2319-7668

\begin{tabular}{|l|l|l|l|l|l|}
\hline $\begin{array}{l}\text { Recognition } \\
\text { motivates the } \\
\text { teachers. }\end{array}$ & 25 & 21 & 4 & & \\
\hline
\end{tabular}

Mostly respondents are satisfied with the given statement. But most of respondent are affected by the recognition. Due to recognition their level of satisfaction increases. Praise from administer, parents, students etc has great affect on job satisfaction level of teachers. Recognition motivates them to do their job well. Recognition motivates their level of satisfaction.

TABLE XVIII. Teachers Have Ample Opportunity to Grow

\begin{tabular}{|l|l|l|l|l|l|}
\hline Parameter & $\begin{array}{l}\text { Extremely } \\
\text { Satisfied }\end{array}$ & $\begin{array}{l}\text { Somewhat } \\
\text { Satisfied }\end{array}$ & Neutral & $\begin{array}{l}\text { Somewhat } \\
\text { dissatisfied }\end{array}$ & $\begin{array}{l}\text { Not satisfied at } \\
\text { all }\end{array}$ \\
\hline $\begin{array}{l}\text { Teachers have } \\
\text { ample } \\
\text { opportunity to } \\
\text { grow. }\end{array}$ & 23 & 21 & 6 & & \\
\hline
\end{tabular}

The above table shows that $46 \%$ respondents are extremely satisfied, $42 \%$ are somewhat satisfied and $12 \%$ are neutral. Satisfied respondents feel that their professional growth affects their level of satisfaction. If they get good potential for professional growth then they are more satisfied towards their job. If they get ample opportunity to grow like promotion at high level, increases in their salary increase their level of satisfaction. So ample opportunity to grow motivates the satisfaction level of teachers.

TABLE XIX. Interpersonal Relationships with Colleagues, Students and Administers Motivate/Boost Job Satisfaction level of teachers

\begin{tabular}{|l|l|l|l|l|l|}
\hline Parameter & $\begin{array}{l}\text { Extremely } \\
\text { Satisfied }\end{array}$ & $\begin{array}{l}\text { Somewhat } \\
\text { Satisfied }\end{array}$ & Neutral & $\begin{array}{l}\text { Somewhat } \\
\text { dissatisfied }\end{array}$ & $\begin{array}{l}\text { Not } \\
\text { satisfied } \\
\text { at all }\end{array}$ \\
\hline $\begin{array}{l}\text { Interpersonal relationships with colleagues, } \\
\text { students and administers motivate/boost job } \\
\text { satisfaction level of teachers. }\end{array}$ & 17 & 24 & 3 & 6 & \\
\hline
\end{tabular}

Mostly respondents are satisfied with the given statement. It means interpersonal relation with the colleagues, administers and student has great affect on the job satisfaction of teachers. Their good interpersonal relationships with colleagues, administers and student motivates their satisfaction level towards their job. If teachers has good interpersonal relationships with colleagues, administers and student then they do their job very well and have more satisfaction towards their job than the teachers who have bad interpersonal relationships with administers. Their good Interpersonal relationships with students motivate their level of satisfaction. If teachers have no good Interpersonal relationships with students then their productivity will be low. Their results of teaching will not be good which decreases their level of satisfaction. Thus interpersonal relationships with colleagues, administers and student boost the satisfaction level of teachers.

TABLE XX. Salary Motivates the Satisfaction of Teachers

\begin{tabular}{|l|l|l|l|l|l|}
\hline Parameter & $\begin{array}{l}\text { Extremely } \\
\text { Satisfied }\end{array}$ & $\begin{array}{l}\text { Somewhat } \\
\text { Satisfied }\end{array}$ & Neutral & $\begin{array}{l}\text { Somewhat } \\
\text { dissatisfied }\end{array}$ & $\begin{array}{l}\text { Not satisfied at } \\
\text { all }\end{array}$ \\
\hline $\begin{array}{l}\text { Salary } \\
\text { motivates the } \\
\text { satisfaction of } \\
\text { teachers. }\end{array}$ & 23 & 23 & 3 & 1 & \\
\hline
\end{tabular}


The above table shows that 23 respondents are extremely satisfied, 23 are somewhat satisfied, 3 are neutral and 1 is somewhat dissatisfied from given statement. Salary has great impact on the satisfaction level of teachers. The teacher with more salary is more satisfied than the teacher with less salary. It means salary plays a major role in the job satisfaction of teachers. Teachers with more salary have high level of satisfaction towards their job. Salary motivates the satisfaction level of teachers up to great extent.

TABLE XXI. Job Security of University Teachers Motivate their Satisfaction Level:

\begin{tabular}{|l|l|l|l|l|l|}
\hline Parameter & $\begin{array}{l}\text { Extremely } \\
\text { Satisfied }\end{array}$ & $\begin{array}{l}\text { Somewhat } \\
\text { Satisfied }\end{array}$ & Neutral & $\begin{array}{l}\text { Somewhat } \\
\text { Dissatisfied }\end{array}$ & $\begin{array}{l}\text { Not } \\
\text { satisfied at } \\
\text { all }\end{array}$ \\
\hline $\begin{array}{l}\text { Job security of University } \\
\text { Teachers Motivate their } \\
\text { satisfaction level }\end{array}$ & 26 & 17 & 7 & & \\
\hline
\end{tabular}

Mostly respondents are satisfied from above statement. In public sector the job is more secure than in private sector. But teachers on contract base are insecure towards their job. So job security has less impact on the teachers in public sectors. Teachers in public sector have more job security than teachers in private sector. If job is secure then teachers will do work confidently and better. If the job is insecure then he will be always in tension and will never pay full attention to their work. Job security among university teachers is more which motivates their satisfaction level.

TABLE XXII. Personal Life of Teachers has Great Effect of Motivations Towards their Job

\begin{tabular}{|l|l|l|l|l|l|}
\hline Parameter & $\begin{array}{l}\text { Extremely } \\
\text { Satisfied }\end{array}$ & $\begin{array}{l}\text { Somewhat } \\
\text { Satisfied }\end{array}$ & Neutral & $\begin{array}{l}\text { Somewhat } \\
\text { dissatisfied }\end{array}$ & $\begin{array}{l}\text { Not satisfied at } \\
\text { all }\end{array}$ \\
\hline $\begin{array}{l}\text { Personal life of } \\
\text { Teachers has great } \\
\text { effect of motivations } \\
\text { towards their Job. }\end{array}$ & 25 & 20 & 5 & & \\
\hline
\end{tabular}

Mostly employees are satisfied with above statement. Personal life of a person also motivates his job satisfaction. Personal life of female teachers has great affect on the job satisfaction than the male teachers because female teachers have more responsibilities in their personal life than male teachers. Job satisfaction among female teachers is less than male teachers. Personal life plays an important role to motivate the job satisfaction of teachers. If they have some problems in personal life then they will not pay full attention towards their work which decreases their satisfaction level.

TABLE XXIII. Student's Feedback Acts as a Motivation for Teachers

\begin{tabular}{|l|l|l|l|l|l|}
\hline Parameter & $\begin{array}{l}\text { Extremely } \\
\text { Satisfied }\end{array}$ & $\begin{array}{l}\text { Somewhat } \\
\text { Satisfied }\end{array}$ & Neutral & $\begin{array}{l}\text { Somewhat } \\
\text { dissatisfied }\end{array}$ & $\begin{array}{l}\text { Not satisfied at } \\
\text { all }\end{array}$ \\
\hline $\begin{array}{l}\text { Student's } \\
\text { feedback acts as } \\
\text { a motivation for } \\
\text { teachers. }\end{array}$ & 23 & 18 & 8 & 1 & \\
\hline
\end{tabular}

Mostly respondents are satisfied with above statement. Only one respondent is not satisfied with given statement. Student's feedback plays great role to motivate job satisfaction of teachers. Feedback from students has great impact on the motivation and satisfaction level of teachers. Positive feedback from student motivates the satisfaction level of teachers if students are satisfied from their teachers then they will give positive feedback to their teachers which motivate the satisfaction level of teachers. 


\section{CONCLUSION}

To conclude, the present study found a significant positive relationship between job satisfaction and motivation. The present study attempts to examine the relationship between job satisfaction and motivation among University teachers. The data was collected from 50 University Teachers. The Teachers were surveyed by questionnaire. The sample was drawn by using the convenient Non-random sampling technique. The results showed a significant positive relation between job satisfaction and motivation. This signifies that higher the job satisfaction, lower is the intent of a person to quit the job. This shows that job satisfaction or dissatisfaction plays a significant role in influencing the Motivation level of University teachers.

\section{REFERENCES}

[1] J. S. Adams, "Towards understanding of Inequity", Journal of Abnormal and Social Psychology, 67, $1963,422-436$.

[2] E. E. Clark, "Job Satisfaction in Britain", British Journal of Industrial Relations, 34(2), 1996, 189-217.

[3] A. Clark, A. Osward, and P. Warr, "Is Job Satisfaction is U Shaped", Journal of Occupational and Organizational Psychology, 69, 1996, 57-81.

[4] S. Bose and M. Agarwal, "Work Environment and Perceived Fulfillment of Psychological Contrast: A Study of Private and Public Sector Organisations", Indian Journal of Industrial Relations, 38(4), 2003, 460-479.

[5] S. Mahajan, "Impact of Certain Demographic Variables on Organizational Role Stress", Indian Management Studies Journal, 6, 2002.

[6] C. M. Hellman, "Job Satisfaction and Intent to Leave", Journal of Social Psychology, 137(6), 1997, 677-689.

[7] K. Lindstorm, "Age-Related Differences in Job Characteristics and in their Relation to Job Satisfaction", Scandinavian Journal of Work, Environment and Health, 14(1), 1988, 24-26.

[8] N. Nicholson, C. A. Brown and T. K. Chandwick, "Absence from Work and Job Satisfaction", Journal of Applied Psychology, 61, 1976, 728-737.

[9] R. Thahier, S. Ridjal and F. Risani, "The influence of leadership style and motivation upon employee performance in the provincial secretary office of West Sulawesi”, International Journal Of Academic Research, 6(1), 2014.

[10] A. H. Maslow, (1943). A theory of Human Motivation. Psychological Review, 50, p. 370.aslow, A. H. (1970). Motivation and Personality, (2), New York: Harper and Row.

[11] G. Dessler, Management: Leading People and Organization in the 21st Century (Harlow: Prentice Hall, 2001).

[12] S. P. Robbins, Organizational Behavior: Concepts, controversies and applications (New Delhi: Prentice Hall, 1998).

[13] F. Luthans and R. Kreitner, Organizational Behavior Modification, 1985.

[14] E. A. Locke, "The Nature and Causes of Job Satisfaction", M. D. Dunnette, Handbook of Industrial and Organizational Psychology, Rand McNally, Chicago, 1976, 1297-1349.

[15] B. Aziri, "Job Satisfaction: A literature review of management, research and practice", 3(4), 2011, 2011, 77-86.

[16] C. Kyriacou, "Teacher stress and burnout: An international view”, Educational Research, 29, 1987, $146-152$.

[17] J. Mohan and M. Riar, "A Study of Job Satisfaction and its Correlates in Prison Officers", Indian Psychological Review, 48(2), 1997, 67-74.

[18] Nirmala, "Occupational Stress and Job Performance: A Study in Banking Industry", PIMR, 6(1-2), 2002.

[19] Indian Education Commission "Annual Report" 1966.

[20] S.P. Anand, "School Teachers: Job Satisfaction Vs xtraversion and Uroticism", Indian Educational Review, 12(2), 1977, 68 - 78.

[21] R. Goel, Job Satisfaction and its Correlates: An Exploratory Study, Unpublished M. A. Dissertation in Psychology, University of Delhi, Delhi, 1987.

[22] J. Weitz, "A Neglected Concept in the Study of Job Satisfaction", Personnel Psychology, 5, 1952, 201-205.

[23] V. F Filak and K. M. Sheldon, "Student Psychological Need Satisfaction and College Teacher-Course Evaluations", Educational Psychology, 23(3), 2003, 235-247.

[24] M. Singh, and D.M. Pestonjee, "Job Involvement, Sense of Participation and Job Satisfaction: A Study in Banking Industry", Working Paper Series, IIM, Ahmedabad, 1990.

[25] R. T. Mowday, L. W. Porter and R. M. Steers, "Employee - Organization Linkages: The Psychology of Commitment. Absenteeism and Turnover", Academic Press: New York, 1982).

[26] N. P. Ololube, "Professionalism: An Institutional Approach to Teachers' Job Effectiveness in Nigerian Schools", Proc. $7^{\text {th }}$ Int. Line Conf., 2004, 23-25. 